\title{
JIMI
}

\section{Nasabah Mengambang (Floating Customers) pada Bank Syariah di Kota Pontianak}

\author{
Sarah Putri Cahyani
}

Prodi Ekonomi Islam, Fakultas Ekonomi dan Bisnis, Untan, INDONESIA, email: sarahcahyani97@gmail.com

\begin{abstract}
ABSTRAK
Penelitian ini bertujuan mengidentifikasi faktor-faktor apa yang mempengaruhi prilaku nasabah mengambang pada perbankan syariah di Kota Pontianak. Metode penelitian menggunakan analisis skala likert, dengan meneliti 31 responden. Hasil penelitian menunjukkan faktor motif keuntungan dan kualitas pelayanan memiliki pengaruh positif dan kuat dalam menjelaskan prilaku nasabah mengambang pada perbakan syariah di kota Pontianak.
\end{abstract}

Kata kunci: Floating customers, Kualitas pelayanan, Religiusita, perbankan syariah. 


\section{PENDAHULUAN}

Pasar nasabah mengambang (floating customers) dalam perbankan syariah memiliki potensi yang besar, mencapai hingga Rp. 720 triliun. Besaran loyalitas nasabah pada bank konvensional yaitu Rp. 240 triliun dan loyalis syariah yang hanya sebesar Rp. 10 triliun (Karim dan Affif, 2008). Potensi yang besar mendorong perbankan berlomba-lomba untuk berkompetisi merebut pangsa pasar floating customers. Baik dari segmen loyalis syariah, loyalis konvensional, maupun floating customers memiliki beberapa kesamaan dalam memilih lembaga keuangan untuk menyimpan dana, yaitu koneksi kantor dan ATM yang luas, kualitas pelayanan, serta kedudukan bank itu sendiri. Adapun perbedaannya hanya dari prioritasnya (Mursid dan Irviana, 2012).

Nasabah mengambang dapat ditinjau dari teori perilaku konsumen (consumers behavior), dimana konsumen cenderung melakukan kegiatan konsumsi atau terlibat dalam kegiatan lembaga keuangan disebabkan berbagai faktor yang meliputi seluruh kehidupannya, mulai dari usia, pendidikan, budaya, keluarga, keadaan ekonomi, dan lain-lain. Hal ini mengindikasikan pentingnya mempelajari perilaku konsumen dan mengidentifikasi faktor-faktor konsumen dalam melakukan aktivitas ekonomi (Schiffman dan Kanuk, 2008; Karin dan Affif, 2006).

Islam memandang perilaku nasabah mengambang sebagai perilaku labil, dimana meskipun nasabah menggunakan bank syariah dalam aktivitas ekonominya, namun ia juga menggunakan bank konvensional yang mengandung unsur-unsur yang dilarang dalam Islam, terutama dalam hal riba. Perilaku ini sebagaimana dijelaskan dalam QS. Al-Hajj ayat 11:

Artinya: "Dan di antara manusia ada orang yang menyembah Allah dengan berada di tepi; maka jika ia memperoleh kebajikan, tetaplah ia dalam keadaan itu, dan jika ia ditimpa oleh suatu bencana, berbaliklah ia ke belakang. Rugi lah ia di dunia dan di akhirat. Yang demikian itu adalah kerugian yang nyata."

Ayat di atas menunjukkan perilaku labil manusia menyebabkan kerugian dunia akhirat. Adapun dalam fenomena floating customers, maka perlu dirinci alasan seseorang menjadi nasabah mengambang, dimana tidak seluruh kegiatan pada bank konvensional itu dilarang, seperti transfer antar bank dengan biaya pengiriman, penerbitan anjungan tunai mandiri (ATM), dan safe-deposit box (SDB).

Berdasarkan data pra-survei yang dilakukan oleh peneliti, dari 31 responden terhadap nasabah mengambang, ditemukan bahwa mereka memiliki minimal satu rekening di bank syariah dan bank konvensional secara bersamaan. Hasil pra-survei menunjukkan fenomena jumlah floating customers di Kota Pontianak yang lebih tinggi dibanding rata-rata floating customers di Indonesia yaitu 55,8\%. Hal ini menarik diteliti dengan tujuan menguji dan menganalisis hubungan besaran keuntungan, kualitas pelayanan, dan tingkat religiusitas terhadap nasabah mengambang (floating customers) di Kota Pontianak.

\section{LANDASAN TEORI}

Teori perilaku konsumen salah satunya menggolongkan nasabah dalam kategori loyal dan tidak loyal (Kasali, 1998). Loyalitas bisa bertumpu pada merek, wilayah asal, keunikan, rasa, dan termasuk faktor keagamaan. Loyalitas atau tidak juga tegantung pada tingkat usia, pendidikan, kebudayaan, kondisi sosial dan ekonomi lainnya (Schiffman dan Kanuk, 2008). Perilaku konsumen merupakan segala 
tindakan, kegiatan, dan proses psikologis yang mendorong dilakukannya tindakan baik sebelum melakukan pembelian, saat membeli, menggunakan, menghabiskan barang dan jasa serta evaluasi. Nasabah mengambang (floating customers) memiliki kecenderungan untuk mendapatkan benefit sehingga tidak begitu mementingkan unsur segi transaksi yang ada pada perbankan, baik dalam aspek syariah atau tidaknya. Kecenderungan memilih benefit mendorong pemikiran nasabah mengambang untuk selalu mendapat cara mudah dan instan dalam melakukan transaksi perbankan yang efisien, menjanjikan dan tentunya mendapat imbal balik setimpal (Helmy, 2013).

Dalam kaitannya dengan perbankan syariah, nasabah mengambang di kaitkan dengan adanya indikasi nasabah memiliki sejumlah rekening secara bersama yaitu rekening pada bank syariah dan pada bank konvensional. Karim dan Affif (2008) telah melakukan penelitian terhadap nasabah mengambang dengan beberapa indikator, dan menemukan bahwa beberapa nasabah muslim mengambang mengesampingkan anggapan bunga bank itu haram, karena yang dikatakan haram yaitu riba bukannya bunga bank. Menurut Helmy (2013) orang yang hobi membaca buku, berita dan mencari informasi floating mass market lebih bersifat selalu membandingkan derajat biaya dan manfaat suatu produk, sehinga cenderung membuat mereka labil.

Ada beberapa faktor yang menyebabkan sesorang menjadi floating customers. Putong (2008) menunjukan faktor besaran keuntungan atau mencari manfaat material yang lebih adalah salah satu faktor penting. Disamping itu kualitas pelayanan merupakan kegiatan yang menolong menyediakan segala apa yang diperlukan konsumen sehingga diperoleh kepuasan pelanggan merupakan faktor penentu floating customer lainnya (Sedyana, 1995). Kualitas jasa (service quality) memiliki lima dimensi yaitu berwujud (tangible), keandalan (reliability), ketanggapan (responsiveness), jaminan dan kepastian (assurance), dan empati (empathy) (Lupiyoadi dan Hamdani, 2006). Faktor religiusitas dinilai penting dalam menentukan loyalitas produk. Keputusan konsumen membeli produk tergantung kepada kadar keimanan mereka (Nasrullah, 2015). Terdapat lima dimensi religiusitas sebagaimana yang diutarakan Glock (2003) dalam Mayasari (2014), yaitu dimensi ideologi, peribadatan, penghayatan, pengetahuan, dan pengamalan. Produk yang halal dan toyib menjadi faktor menuju loyalitas regelius.

\section{METODE PENELITIAN}

Penelitian ini berbentuk deskriptif melalui pendekatan gabungan antara kualitatif dan kuantitatif. Data yang digunakan bersumber dari interview yang dibantu dengan angkat wawancara terhadap 31 responden (nasabah) perbankan syariah yang memiliki rekening tabungan ganda (syariah dan kovensional) secara bersama. Penelitian dilakukan tahun 2019 di Kota Pontianak. Teknik pengambilan sampel menggunakan menggunakan teknik sampek random (non-probably sampling) yang disesuaikan dengan tujuan penelitian ( purposive sampling).

\section{Uji kualitas data}

Uji kualitas data dilakukan dengan uji validitas dan uji reliabilitas. Uji validitas dilakukan untuk menguji ketelitian atau ketepatan alat ukur terhadap data aktual. Uji ini dilakukan dengan mengorelasikan jawaban tiap-tiap item pertanyaan dengan total item. Apabila koefisien korelasi lebih besar daripada r-tabel maka disimpulkan item telah valid dan dapat dilanjutkan dengan uji reliabilitas. Uji reliabilitas 
dilakukan setelah dilakukan pengujian validitas. Uji ini dilakukan untuk melihat konsistensi instrumen penelitian manakala dilakukan penelitian berulang dengan instrumen yang sama. Suatu instrumen dinyatakan reliabel apabila memiliki nilai Cronbach's alpha lebih dari 0,6.

\section{Uji koefisien korelasi rank Spearman}

Uji ini merupakan bagian dari uji statistik non-parametris digunakan untuk menguji hubungan antara dua variabel yang berjenis data ordinal. Uji ini tidak memerlukan asumsi linieritas, dan data tidak harus berdistribusi normal. Adapun persamaan korelasi rank Spearman dinotasikan sebagai berikut (Sugiono, 2016):

$$
\left.\rho=1-\frac{6 \sum b_{i}^{2}}{n\left(n^{2}-1\right)} 1\right)
$$

Keterangan:

$\boldsymbol{\rho} \quad$ : Koefisien Korelasi Rank Spearman

$\mathbf{b}_{\mathbf{i}} \quad$ : Selisih ranking antar variabel

n : Jumlah Responden

Untuk menguji signifikansi dari korelasi antar variabel yang diuji, maka dasar pengambilan hipotesis nya adalah sebagai berikut:

1) Jika $\rho$ hitung $<\rho$ tabel atau prob. $>$ taraf signifikansi, maka $\mathrm{H}_{0}$ diterima, tidak terdapat hubungan antara kedua variabel yang diuji.

2) Jika $\rho$ hitung $>\rho$ tabel atau prob. < taraf signifikansi, maka $\mathrm{H}_{\mathrm{a}}$ diterima, terdapat hubungan antara kedua variabel yang diuji.

\section{Uji koefisien determinasi $\left(R^{2}\right)$}

Uji koefisien determinasi dilakukan untuk melihat seberapa banyak variasi variabel terikat dijelaskan oleh variabel bebas. Koefisien determinasi merupakan kuadrat dari koefisien korelasi rank Spearman. Uji ini akan mengetahui derajat keeratan masing-masing faktor.

\section{HASIL DAN PEMBAHASAN}

\section{Karakteristik responden}

Penelitian ini telah mengindektifikasi responden berdasarkan interview langsung dan sebaran angket. Hasilnya menujukan bahwa $71 \%$ nasabah mengambang adalah wanita. Berbading hanya $29 \%$ laki-laki (Tabel 1). Hal ini menunjukan wanita memiliki potensi memiliki rekening lebih banyak dari laki-laki. Fakta ini me nunjukan bahwa kepatuhan syariah kaum wanita terhadap bank syariah relative lebih longgar dari kaum pria.

Tabel 1: Karakteristik responden berdasarkan jenis kelamin, usia, pendidikan dan pekerjaan

\begin{tabular}{l|l|c|c}
\hline Indikator & \multicolumn{1}{|c|}{ Sub-Indikatroo } & Frekuensi & Prosentase (\%) \\
\hline \multirow{3}{*}{ Jenis kelamin } & Laki-laki & 9 & 29 \\
& Perempuan & 22 & 71 \\
& Jumlah & 31 & 100 \\
\hline \multirow{5}{*}{ Usia } & $20-30$ tahun & 4 & 12,9 \\
\cline { 2 - 4 } & $31-40$ tahun & 5 & 16,1 \\
\cline { 2 - 4 } & $41-50$ tahun & 13 & 41,9 \\
\cline { 2 - 4 } & $51-60$ tahun & 7 & 22,6 \\
\cline { 2 - 4 } & $>60$ tahun & 2 & 6,45 \\
\cline { 2 - 4 } & Jumlah & 31 & 100 \\
\hline
\end{tabular}




\begin{tabular}{|c|c|c|c|}
\hline \multirow[t]{6}{*}{ Pendidikan } & $\mathrm{SD} / \mathrm{MI}$ & - & - \\
\hline & SMP/MTS & - & - \\
\hline & SMA/MA & 8 & 25,8 \\
\hline & Diploma & 1 & 3,22 \\
\hline & Sarjana & 22 & 71,00 \\
\hline & Jumlah & 31 & 100 \\
\hline \multirow[t]{5}{*}{ Pekerjaan } & Sedang Kuliah & 3 & 9,67 \\
\hline & Wirausahawan & 15 & 48,4 \\
\hline & Karyawan Swasta & 6 & 19,3 \\
\hline & Pegawai Negeri & 7 & 22,6 \\
\hline & Jumlah & 31 & 100 \\
\hline \multirow{5}{*}{ Pendapatan } & $0-999.999$ & 0 & 0 \\
\hline & $\begin{array}{l}1.000 .000- \\
4.999 .999\end{array}$ & 8 & 26 \\
\hline & $\begin{array}{l}5.000 .000- \\
9.999 .999\end{array}$ & 10 & 32 \\
\hline & $>10.000 .000$ & 13 & 42 \\
\hline & Jumlah & 31 & 100 \\
\hline
\end{tabular}

Dari Tabel 1 terlihat bahwa proporsi nasabah mengambang umumnya berusia diatas 40 tahun. Kelompok terbesar nasabah mengambang berada pada usia 40 - 50 tahun, sebuah usia yang masih produktif dan sedang memasuki masa kejayaan ekonomi. Padahal dari segi agama, pada usia ini sedang memasuki usia menuju senja dan semestinya lebih banyak patuh syariah. Di samping itu, nasabah mengambang banyak berada pada tingkat pendidikan atas (sarjana) yang mencapai $70 \%$, dan di urutan ke dua adalah pada pendidikan SLTA (25 \%).

Hampir separuh respendon adalah kalangan wiruasahwan (Tabel 1). Kalangan inilah yang paling banyak menggunakan rekening bank karena tingginya aktifitas transaksi mereka. Jika dilihat dari karakteristik ini, adalah wajar kalau potensi nasabah mengambang pada kelompok yang beraktifitas tinggi. Pada kalangan pegawai negeri hanya $22 \%$ demikian juga swasta tidak banyak jauh berbeda. Tabel 1 juga menginformasikan bahwa makin tinggi tingkat pendappatan seseorang maka makin besar potensi memiliki tabungan ganda (syariah dan non syariah). Fenomena ini berkaitan dengan besarnya sebaran penggunaan rekening pada orang berpendapatan tinggi dibandingkan berpendapatan rendah.

Responden nasabah mengambang umumnya sebagai wirausaha. Hal ini cukup beralasan karena mereka memerlukan lebih banyak rekening untuk menfasilitasi transaksi-transaksi mereka kepada pihak ketiga. Belum tentu mereka tidak loyal pada bank syariah, tetapi mereka terpaksa menggunakan rekening bank konvensional untuk kemudahan dan mematuhi permintaan rekan bisnis mereka. Nasabah dengan status sebagai pegawai negeri juga merupakan urutan ke dua terbanyak, hal ini karena umumnya pegawai negeri diharuskan membuta rekening pada bank yang dirujuk oleh instansi mereka untuk pembayaran gaji.

Pada Tabel 1 terlihat bahwa makin tinggi pendapatan maka makin besar potensi untuk tidak loyal kepada satu bank syariah saja. Mereka memiliki uang yang cukup sehingga berpotensi menabung dalam ragam bank yang berbeda. Pada kelompok berpendapatan tinggi ini cenderung mencari manfaat ekonomi dari penempatan tabungan mereka di berbagai bank, baik syariah ataupun bukan. 


\section{Rekening yang dimiliki dan tahun membuka rekening}

Untuk mengetahui jumah rekening dan kapan mereka membuka ataupun keluar dari sebuah bank syariah dapat dilihat dari Tabel 2. Ditemukan sebagai kecil responden yang memiliki rekening sampai 4 buah. Namun jumlah responden dengan tabungan sebanyak 3 buah cukup besar. Jumlah tabungan sebanyak 3 dan 4 buah mencapai $42 \%$, suatu jumlah yang tidak sedikit. Ini relative seimbangan dengan responden dengan jumlah tabungan 2 buah.

Tabel 2: Rekening yang dimiliki dan tahun membuka rekening

\begin{tabular}{llcc}
\hline No. & Tahun Membuka Rekening & $\begin{array}{c}\text { Bank } \\
\text { Syariah }\end{array}$ & $\begin{array}{c}\text { Bank } \\
\text { Konvensional }\end{array}$ \\
\hline 01 & $2002,2005,2011^{*}$ & 1 & 2 \\
02 & $2000,2016^{*}, 2019$ & 1 & 2 \\
03 & $2014,2015^{*}, 2016$ & 1 & 2 \\
04 & $2008,2010,2016,2017^{*}, 2018^{*}$ & 2 & 3 \\
05 & $2005,2010,2012,2018^{*}$ & 1 & 3 \\
06 & $1998,2006,2008^{*}, 2012^{*}$ & 2 & 2 \\
07 & $2001,2006,2017^{*}$ & 1 & 2 \\
08 & $2000,2017,2018^{*}$ & 1 & 2 \\
09 & $2016,2018,2019^{*}$ & 1 & 2 \\
10 & $2001,2009^{*}, 2011,2017$ & 1 & 3 \\
11 & $2007,2015,2018^{*}$ & 1 & 2 \\
12 & $2013,2015^{*}, 2017$ & 1 & 2 \\
13 & $1992,2010^{*}, 2014,2015$ & 1 & 3 \\
14 & $2013,2014^{*}, 2017$ & 2 & 3 \\
15 & $2010,2011,2014,2015^{*}, 2017^{*}$ & 1 & 2 \\
16 & $2009,2011,2015^{*}$ & 1 & 4 \\
17 & $2011,2012,2014,2015,2018^{*}$ & 1 & 2 \\
18 & $2000,2006,2015^{*}$ & 1 & 3 \\
19 & $2009,2010,2011^{*}, 2012$ & 1 & 2 \\
20 & $2011,2013,2015^{*}$ & 1 & 3 \\
21 & $2009,2012,2017,2018^{*}$ & 1 & 3 \\
22 & $2009,2010,2012^{*}, 2015$ & 2 & 3 \\
23 & $2003,2011,2012,2017^{*}, 2018^{*}$ & 1 & 4 \\
24 & $2002,2005,2007,2010,2015^{*}$ & 1 & 3 \\
25 & $2011,2013,2015,2016^{*}$ & 1 & 2 \\
26 & $2005,2015^{*}, 2017$ & 1 & 2 \\
27 & $2009,2016^{*}, 2017$ & 1 & 2 \\
28 & $2015,2016,2017^{*}$ & 1 & 2 \\
30 & $2014,2015,2017^{*}, 2018^{*}, 2019$ & 1 & 2 \\
31 & $2015,2016,2019^{*}$ & 1 & 2 \\
\hline 5 & $2017^{*}, 2018,2019$ & 1 & 2 \\
\hline
\end{tabular}

Sumber: Hasil Pengolahan Data Primer (Data diolah, 2020)

Tanda * artinya : memiliki rekening bank syariah pada tahun tertera.

Berdasarkan Tabel 2, berdasarkan tahun membuka rekening tercatat bahwa:

a. Pindah satu arah ke syariah. Nasabah bank konvensional yang pindah ke bank syariah sebanyak 19 orang (61,3\%). Pindah satu arah.

b. Pindah ulak alik. Nasabah mengambang bank konvensional pindah ke bank syariah lalu pindah lagi ke bank konvensional sebanyak 11 orang $(35,5 \%)$, 
c. Pindah ke non syariah. Nasabah mengambang yang berpindah dari bank syariah ke bank konvensional sebanyak 1 orang $(3,2 \%)$.

Dapat dilihat bahwa lebih banyak responden nasabah mengambang berasal dari bank konvensional pindah ke bank syariah. Meskipun begitu nasabah tetap tidak bisa lepas dari bank konvensional maupun dari bank syariah dikarenakan nasabah mengambang cenderung suka membandingkan antara bank konvensional dan bank syariah.

\section{Hasil Uji Kualitas Data Uji Validitas}

Tabel 3: Hasil uji validitas instrumen

\begin{tabular}{llllc}
\hline Variabel & Indikator & r hitung & r tabel & Keterangan \\
\hline \multirow{4}{*}{ Keuntungan (X1) } & X1.1 & 0,682 & 0,3550 & Valid \\
& X1.2 & 0,818 & 0,3550 & Valid \\
& X1.3 & 0,812 & 0,3550 & Valid \\
& X1.4 & 0,450 & 0,3550 & Valid \\
\hline \multirow{4}{*}{ Pelayanan (X2) } & X2.1 & 0,479 & 0,3550 & Valid \\
& X2.2 & 0,719 & 0,3550 & Valid \\
& X2.3 & 0,719 & 0,3550 & Valid \\
& X2.4 & 0,731 & 0,3550 & Valid \\
& X2.5 & 0,622 & 0,3550 & Valid \\
\hline \multirow{2}{*}{ Religiusitas (X3) } & X3.1 & 0,582 & 0,3550 & Valid \\
& X3.2 & 0,773 & 0,3550 & Valid \\
& X3.3 & 0,584 & 0,3550 & Valid \\
& X3.4 & 0,726 & 0,3550 & Valid \\
\multirow{2}{*}{ Nasabah Mengambang (Y) } & X3.5 & 0,622 & 0,3550 & Valid \\
& Y1 & 0,792 & 0,3550 & Valid \\
& Y2 & 0,711 & 0,3550 & Valid \\
\hline
\end{tabular}

Sumber: Hasil pengolahan data melalui SPSS 25 (Data diolah, 2020)

Hasil uji validitas menunjukkan $r$ hitung yang lebih besar daripada $r$-tabel pada seluruh item pertanyaan sehingga disimpulkan kuesioner telah valid dan dapat dilanjutkan uji reliabilitas.

\section{Uji Reliabilitas}

Tabel 4: Hasil uji reliabilitas (Cronbach's Alpha)

\begin{tabular}{lcc}
\hline Variabel & Cronbach's Alpha & Keterangan \\
\hline Besaran Keuntungan & $0.701>0,6$ & Reliabel \\
\hline Kualitas Pelayanan & $0.696>0,6$ & Reliabel \\
\hline Tingkat Religiusitas & $0.721>0,6$ & Reliabel \\
\hline Nasabah Mengambang & $0.721>0,6$ & Reliabel \\
\hline \multicolumn{2}{l}{ Sumber: Hasil pengolahan data melalui SPSS 25 (Data diolah, 2020) } &
\end{tabular}

Berdasarkan nilai Cronbach's alpha seluruh variabel penelitian lebih besar daripada 0,6 maka disimpulkan kuesioner penelitian reliabel untuk dilakukan pengambilan data secara berulang kali.

Hasil uji koefisien korelasi rank spearman dan koefisien determinasi $\left(\mathrm{R}^{2}\right)$

Tabel 5: Hasil uji koefisien korelasi rank Spearman dan koefisien determinasi $\left(\mathbf{R}^{2}\right)$

\begin{tabular}{lccc}
\hline Variabel & $\begin{array}{l}\text { Koefisien Korelasi } \\
\text { Rank Spearman }(\rho)\end{array}$ & Signifikansi & $\begin{array}{l}\text { Koefisien Determinasi } \\
\left(\mathrm{R}^{2}\right)\end{array}$ \\
\hline Besaran keuntungan $(\mathrm{X} 1)$ & 0.44 & $0.013^{*}$ & 0.194
\end{tabular}




$\begin{array}{lccc}\text { Kualitas pelayanan (X2) } & 0.41 & 0.022^{* *} & 0.168 \\ \text { Tingkat religiusitas (X3) } & -0.321 & 0.079 * * & 0.103\end{array}$

Keterangan: *signifikan pada taraf 5\% | **signifikan pada taraf $10 \%$

Sumber: Hasil pengolahan data melalui SPSS 25 (Data diolah, 2020)

Berdasarkan tabel 5 menunjukkan besaran keuntungan dan kualitas pelayanan berhubungan nyata terhadap nasabah mengambang di Kota Pontianak pada taraf signifikansi 5\%, sementara tingkat religiusitas berhubungan nyata pada taraf signifikansi 10\%. Derajat korelasi besaran keuntungan dan kualitas pelayanan terhadap nasabah mengambang berada pada tingkat sedang dengan arah positif yang ditunjukkan oleh nilai $\rho$ berturut-turut 0,44 dan 0,41 . Adapun tingkat religiusitas memiliki derajat korelasi rendah dengan arah negatif yang ditunjukkan oleh $\rho$ sebesar $-0,321$.

Hasil uji menunjukkan besaran keuntungan, kualitas pelayanan, dan tingkat religiusitas dapat menjelaskan variasi nasabah mengambang di Kota Pontianak berturut-turut sebesar 19,4\%; 16,8\%, dan 10,3\%. Hasil penelitian ini sejalan dengan penelitian Sybly (2009); Irbid dan Zarka (2001) menyatakan tingkat keuntungan berpengaruh positif terhadap nasabah mengambang. Penelitian Silviana dan Putra (2017) variabel kualitas pelayanan berpengaruh positif terhadap nasabah mengambang. Metawa dan Almossawi (1998) menyatakan tingkat religiusitas berpengaruh negatif terhadap nasabah mengambang.

Hasil penelitian mengidentifikasi bahwa makin baik kualitas palayanan dan insentif (manfaat material) yang ditawarkan bank syariah maka berkorelasi positif dengan peluang nasabah untuk memiliki lebih banyak rekening (tidak loyal pada satu bank). Mereka tidak meninggalkan bank yang lama, tetapi menambah rekening bank baru, dan akan meninggalkan rekening lama jika dipandang kurang menguntungan. Faktor keberagamaan berkorelasi negatif dengan potensi loyalitas konsumen. Makin kuat pemahaman beragama seseorang maka makin cenderung mereka loyal terhadap bank syariah. Walaupun mereka termasuk dalam kategori memiliki rekening ganda, tetapi arah menuju loyal cukup terlihat.

\section{KESIMPULAN}

Penelitian ini bertujuan untuk mengidentifikasi faktor-faktor apa yang mempengaruhi nasabah mengambang perbankan syariah di Kota Pontianak dengan analisis deskriptif dan pengumpulan data menggunakan kuesioner skala likert. Penelitian ini mendapatkan hasil besaran keuntungan dan kualitas pelayanan memiliki hubungan nyata arah positif terhadap nasabah mengambang di Kota Pontianak. Hal ini menunjukkan bahwa semakin besar keuntungan dan baik kualitas yang diberikan perbankan, maka semakin tinggi peluang nasabah menempatkan dananya pada perbankan. Namun ketika bank hanya dapat memberikan hasil rendah tentunya nasabah akan beralih ke bank lain. Kemudian tingkat religiusitas memiliki hubungan nyata dan negatif terhadap nasabah mengambang di Kota Pontianak. Hal ini berkaitan dengan semakin tinggi tingkat religiusitas seseorang maka semakin teguh ia memegang prinsip agama Islam, termasuk menghindari riba pada perbankan konvensional sehingga ia semakin loyal terhadap perbankan syariah.

Implikasi dari penelitian ini memberikan informasi berguna bagi pihak perbankan syariah bahwa jika mereka ingin menarik minat nasabah agar loyal maka mereka berusaha untuk menyediakan fasiltas yang memungkinkan nasabah 
memperoleh keuntungan material, seperti berupa insetif bagi hasil, dan menjamin kualitas pelayanan yang lebih baik. Penelitian ini juga menginformasikan bahwa tingkat keperdulian nasabah terhadap kesyariahan produk perbankan syariah masih belum mamadai. Oleh karena itu edukasi tentang pentingnya fiqih muamalah harus terus di dakwahkan oleh para pengiat ekonomi syariah.

\section{DAFTAR PUSTAKA}

Helmy, M. Y. (2013). Deputy Director Karim Consulting Indonesia. Silviana, Interviewer.

Irbid, \& Zarka. (2001). Banking Bahavior of Islamic Bank Costomers: Perspectives and Implication. International of Bank Marketing, 16(7), 299-313

Kasali, R. (1998). Membidik pasar Indonesia: segmentasi, targeting, dan positioning. Gramedia Pustaka Utama.

Karim, A. A., \& Affif, A. Z. (2006). Islamic banking consumer behaviour in Indonesia: a qualitative approach. In 7th International Conference on Islamic Economics (pp. 1-19).

Kementerian Agama, R. I. (2012). Al-Qur'an dan Terjemahannya, Jakarta: PT. Sinergi Pustaka Indonesia.

Lupiyoadi, H., \& Hamdani, A. (2006). Manajemen Pemasaran Jasa, Edisi Kedua. Jakarta: Penerbit Salemba Empat, 525.

Mayasari, R. (2014). Religiusitas Islam dan kebahagiaan (sebuah telaah dengan perspektif psikologi). Al-Munzir, 7(2), 81-100.

Metawa, S. A., \& Almossawi, M. (1998). Banking behavior of Islamic bank customers: perspectives and implications. International Journal of Bank Marketing, Vol. 16 No. 7, pp. 299-313. .

Mursid, M. C., \& Irviana, R. K. (2012). Analisis Segmen Pasar dan Perilaku Nasabah Bank Syariah: Kajian Hukum Islam Terhadap Produk HSBC Amanah Indonesia. Al-Iqtishad: Jurnal Ilmu Ekonomi Syariah, 4(2).

Nasrullah, M. (2015). Islamic Branding, Religiusitas dan keputusan konsumen terhadap produk. Jurnal Hukum Islam, 13(2), 79-87.

Putong, I. (2005). Teori Ekonomi Mikro Kajian Konvensional dan Wacana Syariah. Jakarta: Mitra Wacana Media.

Rakhi, H. (2019). Analisis Pengaruh Labelisasi Halal Terhadap Keputusan Pembelian Produk Kosmetik: Studi Kasus Kota Pontianak. ISLAMICONOMIC: Jurnal Ekonomi Islam, 10(1).

Schiffman, L., \& Kanuk, L. L. (2008). Perilaku konsumen edisi 7. Indeks, Jakarta.

Sedyana. (1995). Perilaku Konsumen. Bandung. Pressko.

Silviana, S., \& Putra, P. (2017). Model Aida Sebagai Strategi Pemasaran Bagi Nasabah Mengambang Perbankan Syariah (Survei Masyarakat Di Kota Bekasi). Jurnal Organisasi dan Manajemen, 13(1), 10-21.

Sugiono, S. (2016). Metode Penelitian Kuantitatif, Kualitatif, dan $R$ \& D. Bandung: Alfabeta.

Syibly, M. R. (2009). Mengkaji Kebutuhan Floating Market Muslim Terhadap Bank Syariah (Studi Kasus Anggota Pengajian Bisnis Al-Kautsar NU di Wilayah DIY). Millah: Jurnal Studi Agama, 8(1), 89-106. 